\title{
On Memory Politics and Memory Wars: A Critical Analysis of the Croatian Dialogue Document
}

\author{
HRVOJE CVIJANOVIĆ \\ Faculty of Political Sciences, University of Zagreb
}

\begin{abstract}
Summary
Based on public demands for rectifying injuries of the past, memory politics recently became the most potent catalyst of social divisions and confrontations, as well as possible limitation of freedom of expression. In addition, facing the past might not yield conciliatory, but rather antagonizing effects, leading toward so-called "memory wars" regarding conflicting past narratives that might jeopardize political stability and aggravate cultural trauma in highly polarized societies, especially if there are powerful mnemonic warriors propelled with foundational and teleological attempts to impose historical "truth", as the author shows in the first part of the article. In the second part the author focuses on the origin of the politics of memory in Croatia and ongoing "memory wars" regarding displaying and using controversial symbolic expressions, while parts three and four contain a critical analysis of the Dialogue Document provided by the Council for Dealing with the Consequences of Undemocratic Regimes that aimed to deliver comprehensive recommendations for political decision-making and law-framing in an attempt to face the difficult past and socially contested symbolic expressions.
\end{abstract}

Keywords: Memory Politics, Memory Wars, Mnemonic Warriors, Disputed Symbols, Croatia, Dialogue Document

"The past is never dead. It's not even past." William Faulkner

\section{Introduction}

In 1657 François Peleau sent the letter to Thomas Hobbes in which he wrote: "I found that, in my opinion, there is now and has always been a war of minds, so far as opinions and feelings are concerned, and that this war is exactly like the state of nature" (Malcolm, 1994: 424). Indeed, it is not hard to make a parallel with today's 
"memory wars" over the interpretation of controversial memories and historical events. As Peleau suggested, "war" should not necessarily be seen as a concept involving physical destruction, but rather, in the case of "memory wars", an ongoing conflict over the meaning, involving contestations about opposing views of history and symbols that deeply polarize and potentially destabilize society. These memory wars have been raging worldwide propelled by various mnemonic actors that use symbols as their weapons in order to unveil hidden injustices or cultural trauma, to commemorate the fallen soldiers or victims of past regimes, or to glorify/condemn certain historical events that were neglected in previous political constellations. The background for the rise of recent memory wars is, depending on the context, different, yet the whole condition can be viewed in a broader sense as a reaction to various political and social changes - from the postcolonial/post-communist discourses of national liberation, the rise of the culture of victimhood and the human rights culture, to the fall of the Enlightenment project ${ }^{2}$ followed by the postmodern/ post-liberal condition and its narrative of the fall of "grand narratives" 3 that, as a consequence, affected the rise of particular national memories. Of course, many are affected. Croatia, Spain, Hungary, Italy, Poland, Russia, Ukraine, South Africa, Argentina, the United States, just to mention a few.

In this article my aim is to show how historical memory and mnemonic actors play a fundamental role in shaping political life in general and in Croatia in particular. For that purpose I have divided the article into four sections. Since memory politics is a reflection of various socio-political activities that can be attributed to mnemonic actors, I will start by providing an account of their foundationalist as

1 "Memory wars" can be linked to the proliferation of political violence based on conflicting and mutually opposed interpretations of historical memories resulting from past traumas, or demands for official endorsement of particular memory-related views. The term has been used, for example, by Gareth Stockey (2013) as a description of ongoing public controversies in contemporary Spain regarding the monument Valley of the Fallen that Francisco Franco erected during his rule to serve as a model for national reconciliation, but more importantly as a glorification of his own regime. The Spanish memory wars are an outcome of the controversy regarding the fallen fascists and their victims from the Spanish Civil War, all buried at this monumental place. Recently, this controversy erupted as a result of Spain's efforts to clarify the status of the monument and of the buried fascist leaders including Franco himself. For example, in Australia similar struggles have been known as the "history wars" regarding the "memorial discourses around genocide in Tasmania" (Gigliotti, 2017: 23).

2 "The Enlightenment project" is a term coined by Alasdair MacIntyre in his book After Virtue (1981) but originated from the criticism of the Enlightenment articulated especially in the midtwentieth century by Max Horkheimer and Theodor Adorno in their Dialectic of Enlightenment (1944) and other writings.

${ }^{3}$ In his seminal work La condition postmoderne (1979), Jean-François Lyotard introduced the rise of "small narratives" instead of so-called "grand narratives" - those dictating the truth for all. 
well as teleological strategies in shaping public discourse on historical memories. These strategies should be viewed central in the politicization of trauma that is important for propelling so-called memory wars for the purposes of establishing a hegemonic view on national memories. This section can be viewed as an introduction into the second part of the article that will focus on the Croatian politics of memory by discussing the origins of memory disputes and recent controversies regarding the display of symbols and symbolic expressions. These origins might be found in various narratives about Croatian history, for example, about Croatia as the Antemurale Christianitatis (Bulwark of Christendom) that was used to legitimize Croatian independence in the 1990s; or more recent disputes regarding the qualification of the Homeland War as defensive, not aggressive that resulted in the Parliament's Declaration on the Homeland War (2000); or dealing with the memories and legacies of undemocratic regimes and their symbols in the Dialogue Document (2018) that attempts to serve as a detailed memory law proposal, and as such it will be the focus of my article in sections three and four. In section three I will thoroughly analyze the narrative of the Dialogue Document provided by the Croatian Council for Dealing with the Consequences of Undemocratic Regimes, while section four will be devoted to the Council's dealings with particular disputed symbolic expressions and its recommendations for their legal regulations. Since the Dialogue Document is the first document in Croatia aiming toward providing comprehensive recommendations for political decision-making and law-framing regarding controversial past regimes and symbols, I will discuss its theoretical shortcomings and internal inconsistencies that have to be taken into account when dealing with the problem of symbolic expressions and memory politics in Croatia. In analyzing this particular case I will provide some relevant case-law examples from the European jurisprudence, more particularly from Hungary, due to the fact that some of these cases have become paradigmatic in discussing contentious symbolic expressions, as well as for the reason Hungary has similar cultural traumas related to fascist and communist terror. The article ends with an epilogue about the detrimental social effects of Croatian memory wars and attempts toward continuous silencing of the past.

\section{Two Faces of Mnemonic Warriors}

Political transformations are seen as an opportunity for new political actors to shape the national mnemonic landscape, especially for those "mnemonic warriors",

4 Bernhard and Kubik focus "on the explosion of the politics of memory triggered by the twentieth anniversary of the fall of state socialism" (Bernhard and Kubik, 2014: 2). They developed the concept of "mnemonic warriors" as one out of four kinds of mnemonic political actors understood as "individuals, parties, organizations, etc." (ibid.: 11). For them these mnemonic warriors can be defined as the mnemonic actors that push for only one version of truth in their nar- 
mythmakers, who, on their mnemonic crusade, zealously impose a single, "truthful" or correct version of history while delegitimizing all views and actors unable to fit under the same mnemonic umbrella. Their take on memories envelops the national past either as nostalgia or trauma. Both need to be alleviated via various commemorative, sacrificial, or glorious recollections often filled with the plethora of martyrs and heroes, all wrapped up in one shared memory ${ }^{5}$ that matters not merely as a reproduction of recollected historic events, but rather as a source for the politicization of memory where "the past is remade in the present for present purposes" (Olick, 1999: 341). This view is important when analyzing so-called mnemonic warriors and their role in influencing politics of memory, especially in highly divided societies dealing with past cultural traumas. In order to understand how such mnemonic cleavages have been fuelled in these societies, I decide to take Bernhard and Kubik's analysis one step further and to argue that mnemonic warriors should be viewed as those propelled with certain important theoretical underpinnings foundational and teleological - that might nurture political instability on the one hand, as well as aggravate cultural trauma on the other.

First, since mnemonic warriors have the perception that they are on the "mission" to deliver or reveal historical truth upon which political entity is founded, they can be regarded as political foundationalists who believe that political entity must necessarily be, or it already is, grounded upon exceptional - and hence foundational - "truthful" historic stories and events - like those about powerful rulers, law-givers, or victorious/traumatic events. They are not necessarily national "Founding Fathers", but might consider themselves as an extension of the founding process by recollecting and defining decisive events constitutive for national state-building. At the same time, that foundational understanding of history is often

ratives related to the national past memories and commemorative politics, and due to their rejection of other possible views on these controversial issues, their non-negotiable mnemonic narratives yield mnemonic cleavages and fractured regimes. Along with the "warriors" they recognize "pluralists" (obviously advocating a pluralist view on national memory), "abnegators" (those not actively interested in the mnemonic narratives), and "prospectives" (oriented toward the future, usually viewed in revolutionary terms, hence not relevant for transitional post-communist societies). The dominance of one mnemonic actor over the other determines "the political form of the official memory regime" (ibid.: 19).

${ }^{5}$ Avishai Margalit makes an important distinction between a common memory and a shared memory. A common memory is just an aggregate notion of "the memories of all those people who remember a certain episode which each of them experienced individually", while a shared memory "requires communication... integrates and calibrates the different perspectives... into one version... Shared memory is torn between two worldviews, which are manifested, in their pure forms, by science on the one hand and by myth on the other" (Margalit, 2002: 51-52, 64). In that sense, the notion of a shared memory plays an important role in the political foundationalism as well as in the process of mythification of national history. 
revealed urbi et orbi through the lenses of the actor's personal story - of personal struggles and reflections - in a way to show the public that there is "a link between history and his personal story, between history and autobiography... in which his self and the history of humanity meet, like two powerful currents, until they reach the point where all masks fall and a mysterious unity is revealed" (Alejandro, 2011: 27). ${ }^{6}$ A mythologized view on history, that Bernal in her seminal work on the concept of founding calls the authoritative beginning, "generates this political foundationalism by eliciting retrospective agreement and establishing grounds for politics and laws" based on self-evident truths and agreements (Bernal, 2017: 4) assuming that history itself is transparent and beyond contestations. In other words, this "originalist account of founding", as called by Bernal, "authorizes without itself needing authorization, since its authority is beyond question", and as she correctly continues, it "renders founding not simply outside history, but also outside legitimation. In that respect, the questions we might ask of the past become muted: questions about past inequalities, democratic deficits, persistent foundational disagreements and conflicts, and, most importantly, past violence and injustices" (ibid.: 38). To conclude, since mnemonic contestations might jeopardize political stability in highly polarized societies the problem with mnemonic warriors is in their "founding" mission - in establishing hegemonic truth, and excluding/delegitimizing their opponents. Such political foundationalism is not attuned to the democratic and pluralist ideal of constitutional democracies, but if successful it might influence shaping memory laws as "the legal governance of history" (Belavusau and Gliszczyńska-Grabias, 2017: 1).

Second, mnemonic warriors can be considered as political teleologists - their locus is not the past alone, but the present or/and future. In other words, while foundational memories are critical for constituting "thick relations" (Margalit, 2002: 7), a popular consensus, or the people having the beginning, origins, state-building, identity, or other similar concepts in a narrative of political liberation and/or rise of a nation, these foundational building-blocks of shared memory lack another key element - a collective telos, a common fate, a point and purpose, along with a mnemonic actor who now, as a political teleologist, emerges as someone able "to express the character of collective life as a project" (Koskenniemi, 2011:25), as someone capable to fill a void in the present and alleviate uncertainty of the future for the average memory-consumer. For such a mnemonic warrior it is crucial to master public frustrations and traumas associated with memories - similarly to the Nietzschean ascetic priest who deals with ressentiment of the masses, and who predates

${ }^{6}$ Actually, this is Alejandro's description of Nietzsche, of what he calls Nietzsche's historiobiography according to which the past resonates in the present through the author himself (Alejandro, 2011). 
over those who "suffer" - those looking for justice, revenge, dignity, or some sense of meaning, no matter how obscure that road might look like. For Nietzsche, the one who rules over the suffering is a master of deceit, yet with a perverse sense of mastering over those defined by suffering - "whilst he soothes the pain caused by the wound, he poisons the wound at the same time" (Nietzsche, 1994: 98) - basically encouraging them to "rummage through the bowels of their past and present for obscure, questionable stories", to "rip open the oldest wounds and make themselves bleed to death from scars long-since healed..." (ibid.: 99). From the perspective of memory politics, such a mnemonic actor provides the average memory-consumer with desired teleological direction vis-à-vis the present and future through permanent unfolding, exploring, mastering, and exploiting of past traumas, victimization narratives, cults of soldiers and soldiering, mourning and sacrifices, heroic deeds, etc. All these serve either as tools for explaining the current social crisis, or for legitimizing public policies regarding memory issues like those of naming or renaming public places, placing or displacing monuments, shaping public discourse and media contents, etc.

These two faces of mnemonic warriors are detrimental for political stability as well as for political pluralism in all societies affected with memory wars since the dominance of these actors in the public space can deepen mnemonic and social divides and aggravate cultural traumas, as many cases show. For instance, this is the case in Spain regarding Franco's legacy, in Italy regarding Mussolini and fascism, in Poland regarding communist terror, in Hungary both with the Nazi and communist past, as it is the case in Croatia. Even though current memory wars reflect already existing ideological cleavages and radically opposed views of national history, recent deployments of memory politics likely entrench the polarized groups regarding their view of particular memory and symbols, or reinforce socio-political dichotomies instead of achieving reconciliatory effects.

In the second part I will focus on the origins of memory politics in Croatia along with its ongoing memory wars, particularly in relation to the socio-political tensions regarding the public display of contested symbols and symbolic expressions; in parts three and four this will be followed by an analysis of the Dialogue Document and its recommendations regarding symbolic expressions.

\section{Land of Confusion: Origins of Memory Politics in Croatia}

In the late 1980s and the beginning of the 1990s past national memories became the source of contestations in the process of political disintegration, state-building and national self-identification. In the light of these historical ruptures, Croatia was becoming socially and politically traumatized, confused, and divided regarding its conflicting narratives about the past. If we put aside the relationship toward 
the "Other", the Croatian political body has been fragmented within, based on the simplified so-called "Ustasha v. Partisans" divide that reflects two conflicting narratives related to Croatian historical experience during World War II (WWII) and the trauma behind them that has been perpetuating socio-political tension from the 1990 s to the present. Soon after the shocking unveilings of crimes related to the Yugoslav regime, especially those in the final days of WWII at Bleiburg and other mass execution sites, ${ }^{7}$ but also those related to communist repression in general in years and decades that followed, the founding narrative of "Brotherhood and Unity" that kept the Yugoslav country of different nations together was understood as a façade. Since the founding narrative collapsed along with the country, it was clear that the new Croatian state would need new founding moments, i.e. a reinvention of binding foundations. Although Bernal, when she discusses the concept of founding, articulates it as "a singular, superlative moment of origin and creation", as well as a "point of consensus, agreement, and civic unity" that becomes "the source of universally binding commitments, beyond and above ordinary politics" (Bernal, 2017: 3), new Croatian political actors were trying to provide a narrative on memory and history beyond a single moment of creation by emphasizing various, "previously unrecognized founding moments" (ibid.: 232) that led to the rebirth of the Croatian state. This new outlook of Croatian founding has been articulated around the trauma of independence lost and regained that has been boiled down to a politicoteleological narrative of Croatian " 1000 year struggle" for independence. The focus of that founding narrative was, of course, the $20^{\text {th }}$-century Croatian struggle against the forces preventing the Croatian nation from fulfilling its centuries-long dream of an independent state. In this narrative the "Serbo-communist conspiracy" has

${ }^{7}$ In Croatian collective memory Bleiburg is a site of cultural trauma as well as a site of contestation. The reason behind these polarized views on Bleiburg is related to the memory of WWII regarding the Yugoslav Partisans' retaliations toward the military of the Ustasha regime of the Independent State of Croatia (Nezavisna Država Hrvatska, or NDH) on the one hand, as well as to the fact that commemoration has been used for some to flirt with the NDH regime, on the other hand. In the article devoted to the controversies regarding the Bleiburg commemoration Pavlaković et al. emphasize: "For the newly independent Croatia, Bleiburg had to be a symbol and metaphor for not only communist crimes committed during the war and immediately after it, but also for forty-five years of authoritarianism" (Pavlaković et al., 2018: 11-12). According to some realistic estimations, at Bleiburg the Yugoslav Army executed about 70000-80000 people (see fn. 6 in: Pavlaković et al., 2018), mostly members of the defeated NDH military accompanied by some civilians, and additionally during the so-called Way of the Cross death marches. However, due to the fact that the Ustasha insignia and symbols can be seen during the commemoration, Austria proposed the new law expected to take force on 1 March 2019 with the expanded list of banned symbols including the Ustasha insignia (see: https:/www.total-croatianews.com/politics/31443-austria-to-expand-list-of-banned-symbols-including-ustasha-insignia (retrieved 4 October 2018). 
played the fundamental role irrespective of whether the focus was the time before WWII or after it in the period of the socialist Yugoslavia to the present. ${ }^{8}$

The point of confusion was the time of WWII. From the perspective of the abovementioned politico-teleological narrative this struggle for an independent state, this trauma of not having an independent state has been embodied in a political entity that actually called itself the Independent State of Croatia (NDH, or Nezavisna Država Hrvatska), no matter how far it was from that description as a fascist creation dependent upon and supported by Nazi Germany. So, in the times of political changes where new founding moments had to be rediscovered and retold, the legacy of the Croatian antifascist movement along with later communist dictatorship (of the proletariat, as the official ideology declared) has been weighed against the NDH project whose reminiscences survived among a part of the Croatian émigrés. Indeed, during political turmoil in which Yugoslav federation was slowly falling apart, Franjo Tuđman, Croatian historian and politician (later the first president of the Republic of Croatia), in his speech given at the $1^{\text {st }}$ General Assembly of the Croatian Democratic Union (HDZ) articulated a new narrative of Croatian political founding that tied the struggle for independence in the past with various aspirations of leading Croatian thinkers and politicians from the $19^{\text {th }}$ and $20^{\text {th }}$ centuries, including Starčević, Radić, and those from the Croatian antifascist left defending the right to self-determination (expressed in the AVNOJ and ZAVNOH principles, i.e. the principles of the Antifascist Council of the National Liberation of Yugoslavia, and the Territorial Antifascist Council of the National Liberation of Croatia). Although Tuđman was clear about reconciling Croatian antifascism and the struggle for independence, his assessment of the NDH was a confusing message to the public, having further implications for developing memory-related disputes, policies, and narratives in Croatia. This is what Tuđman said:

The supporters of hegemonic-unitary or Yugoslav statist views see the HDZ program goals as nothing more than a demand to reestablish the Ustasha NDH. By doing so, they are forgetting that the NDH was not only a mere "Quisling" entity and a "fascist crime", but also an expression of the historic aspirations of the Croatian people to establish their own state. It was also an expression of understanding of international factors, in this case the government of Hitler's Germany, which

${ }^{8}$ For a detailed account of that perception, especially from the 1990 s on, see: Cipek, 2017. He discusses the right-wing perception of that Croatian stereotype: "In the right-wing vision of the world, both the monarchist and the socialist Yugoslavia are thought of only as prisons of nations dominated by the Serbs. And the communist dictatorship - through the theory of totalitarianism - is condemned as even worse than the fascist one, as well as expressed as a collective trauma" (ibid.: 159). Also this perception of the Serbo-communist conspiracy is known under the term "yugo-bolshevism" as one of the important elements in the ideology of Franjo Tuđman (Đurašković, 2016a). 
was, on the ruins of Versailles order, building a New European Order... Therefore, the NDH did not represent a mere whimsy of the Axis Powers, but also a consequence of distinctive historic factors. ${ }^{9}$

While Tuđman's view reflects his overall narrative of political founding that excluded rehabilitation of the crooked NDH regime, a residual footprint of this speech on many party members and supporters was likely different. Among the public it was "understood as a revisionist act" and as such it encouraged "some flirting with the Ustasha" that "were tacitly tolerated in line with the policies of national homogenization and reconciliation" (Pauković, 2012: 207-208). This is evident from the legal and political discourse in the 1990s that was, at the very least, confusing in the message that has been projected into the public.

One of the key moments in Tuđman's attempt to shape memory politics was his project of "national reconciliation" based on a narrative of the unfortunate historical fate of $20^{\text {th }}$-century Croatia being trapped between "the black and red totalitarianism" (Radonić, 2012: 169), or the necessity for healing a divide between two failed Croatian projects - the "black" one, or the one that allied with the fascists and the Nazis during World War II, and the "red" one that has been viewed as an offspring of both communism and antifascism. This was another confusing moment in the Croatian memory politics. Tuđman's project of national reconciliation imagined an overall commemorative monument that would symbolically provide national reconciliation in death for the warring sides of WWII. This controversial idea proposed the bones of the NDH soldiers from Bleiburg, the Way of the Cross, and other mass execution sites to be brought to lie together with the bones of the NDH victims and antifascists in Jasenovac, the notorious WWII Ustasha concentration camp. This bizarre idea that would also symbolically "place the crimes of the Ustasha and the communists on equal ground" (Đurašković, 2016b: 7), was not Tuđman's own. A similar project had already been known as a hallmark of the Spanish fascist dictator Francisco Franco. In an interview for the German Tageszeitung in July 1990 Tuđman emphasized that burying fascist and communist victims together is a pre-

9 See: HDZ Herald, March 1990, p. 18, in: Pauković, 2012: 207, n. 95. For more on the topic, see Pauković's whole chapter The Role of History in Legitimizing Politics in Transition in Croatia. However, in the Historical Foundations of the Croatian Constitution this account of Croatian aspirations was not articulated in that way. Rather, the Constitution explicitly states that Croatian millennial continuity of statehood has manifested itself, among all, "in the establishment of the foundations of state sovereignty during the course of the Second World War, as expressed in the decision of the Territorial Antifascist Council of the National Liberation of Croatia (1943) in opposition to proclamation of the Independent State of Croatia (1941), and then in the Constitution of the People's Republic of Croatia (1947) and in all subsequent constitutions of the Socialist Republic of Croatia (1963-1990)". For the Croatian Constitution, see: http://www. sabor.hr/Default.aspx?art=2406. 
requisite for reconciliation, while in April 1991, for the Croatian magazine Start, he further explained that he took his inspiration from Franco:

It is true that there were victims of fascism, but it is also true that the Croatian people suffered even more, as victims of the [Serbian WWII extreme nationalist movement] Chetniks and Communism. Let's instead erect a monument to everyone, like the one Franco did, in that way making possible the normal development of democracy in Spain. ${ }^{10}$

When Tuđman refers to Franco, he refers to his grandiose memorial entitled the Valle de los Cadíos (Valley of the Fallen) estimated to contain between 30000 and 60000 people buried there. It was a place where all the victims from the Spanish Civil War were buried together (including Franco himself later ${ }^{11}$ ). For Franco, it was an urge to build an official monument of that type for conciliatory purposes. However, Franco's project politicized memories in order to legitimize his view of the state through the discourse of theologico-political "Crusade" - the need for "the heroic sacrifices involved in the victory in war" (Preston, 1995: 42). In Croatia, due to severe criticism and a view that it was highly unethical to have a commemorative place of that sort that puts on an equal footing the perpetrators and their victims, fascists and antifascists, the Croatian version of Franco's Valley of the Fallen in Jasenovac never took place. It would probably aggravate tensions even more and further spark memory wars in Croatia, rather than serve as an example of national reconciliation. Similarly, the whole idea of national reconciliation of the past turned out to be loaded with memories and symbols that could hardly be reconcilable and that were, for these reasons, easily politicized from that time on.

10 See Milekic, 2017.

11 Based on the 2011 recommendations of the Spanish commission for facing the Francoist legacy, the Spanish parliament recently voted to exhumate Franco from the Valley of the Fallen and hence to deprive the monument from being a shrine for Franco's supporters and a continuous glorification of Francoism (see: https://www.independent.co.uk/news/world/europe/francospain-remains-move-civil-war-body-exhumed-relocate-valley-fallen-a8536186.html). The background of this decision is outlined in the Spanish Historical Memory Law (2007). It is interesting that Spain wants other graves of prominent fascists to be removed as well, including those of Ante Pavelić and Vjekoslav Maks Luburić to be returned to Croatia (see: http://www.balkaninsight.com/en/article/ustasa-tombs-in-spain-could-be-removed-07-25-2018). While Ante Đapić, former leader of the Croatian Party of Right (HSP), and current leader of the political party DESNO argued that everyone has a right to be buried in his homeland (https://direktno.hr/direkt/ dapic-direktno-prijenos-posmrtnih-ostataka-poglavnika-pavelica-i-casnika-luburica-hrvatskucivilizac-129303/), Pavelić's family had previously disagreed with the moving since Croatia as it is today is not what Pavelić was fighting for (see: https:/www.jutarnji.hr/vijesti/hrvatska/stoce-biti-s-grobom-ante-pavelica-sedlar-paveliceve-posmrtne-ostatke-ne-bi-bilo-dobro-premjestiti-u-rh/7667385/). 
Another controversy from the early 1990s linked to the beginning of the Homeland War is an absence of resolute political action towards those flirting with the NDH legacy. This issue is related to the military unit of Croatian volunteers whose name, insignia, and especially the salute recently became the focal point of controversy that has been fostering Croatian memory wars. We are talking here of the HOS militia (Hrvatske obrambene snage - Croatian Defense Forces), established during the Homeland War for independence by the Croatian Party of Rights (HSP) that advocated for a resurrection of the NDH. At the level of discourse, it was not a coincidence that the HOS used the historical acronym for the NDH joined military troops from late November 1944 known as the Croatian Armed Forces (Hrvatske oružane snage - HOS, made out of the Home Guards/Domobrani and Ustasha army). Furthermore, after the fall of the NDH regime, the same acronym with the same meaning was used among the Ustasha émigrés as the name for military formations reestablished from "those who managed to flee... located around the globe" (Tokić, 2018: 76) with the goal to operate as a military opposition to the Yugoslav regime. Since picking that acronym did not come out of the blue, this was deliberate flirting with the fascist NDH in which the only important thing was the narrative that this was the entity that reestablished Croatian longings for their own state irrespective of its legal character, the atrocities committed, and the fact that this was neither an independent, nor a sovereign political entity. Hence, this was again flirting with the discredited past and as such a confusing message to the public.

It should be noted that even though Tuđman's memory politics in the early 1990s endorsed the idea of national reconciliation similar to the abovementioned Franco's model, it opposed validating the NDH and Ustasha insignia as legitimate ideas and symbols to be linked with democratic Croatia. This is important to notice in relation to the HOS controversy that has been dividing Croatia until the present time, especially in relation to the insignia they were using during the Homeland War. Even though the HOS was integrated in the Croatian Army during 1992, it was not recognized under this name since the Ministry of Administration in 1995 claimed that "the HOS is not a legal and legitimate form of organizing Croatian citizens in the defense of the Homeland". ${ }^{12}$ This reflects earlier Tuđman's critique of the HOS as the militia "decorated with the Ustasha insignia" $" 13$ that included flirting

12 However, after Tuđman's death, according to the legal framework related to the ways in which civic association can be formed, the Association of the HOS volunteers registered in 2001 along with its For the Homeland Ready insignia. It is ironic that it happened during the left-wing government. See an interview with Dobroslav Paraga, the original organizer of the HOS militia, in Croatian: https://direktno.hr/domovina/udrugu-bojovnika-hos-a-zajedno-s-grbom-i-pozdravomregistrirao-je-sdp-90212/.

13 See Croatian source: Slobodna Dalmacija, 2 September 1992, as well as: Veselinović, 2016: 80. 
with the black color of the uniforms (as it was the color of the NDH Black Legion), as well as with the controversial salute For the Homeland Ready (za dom spremni) known as the official salute of the Ustasha regime. Around the same time in 1992, in an interview for a TV station, Tuđman, while discussing the problem with the HOS volunteers, was clear that memory politics means facing fascism, not flirting with fascist insignia, and embracing antifascism as a standard of narrative in contemporary democracies:

I know that among these young men there were Croatian fanatics, Croatian people who had Croatian ideals, but surprisingly they came to those who dress them into black shirts and fascist marks from the lost World War II. Where would Germany be if it continued the black-shirted and brown-shirted traditions? This was one of the major obstacles to Croatia's international recognition. This is something the world cannot accept. Today's world is built on the principles of the antifascist coalition. $^{14}$

However, Tuđman's public disapproval of this flirting with the Ustasha legacy had no legal consequences, since the government did not ban the usage of these insignia. It shows either the government's tacit tolerance regarding these symbolic expressions, yet without endorsing a free speech argument, or the lack of legal power to translate these verbal criticisms into punitive measures. This absence of a clear stance toward the HOS insignia from the very beginning fosters social confusion regarding the official memory politics, since, as Heinze pointed out, "not to legislate is also to legislate. Legal power acts through law's proceedings but also through law's abstentions" (Heinze, 2017: 420).

But this confusing discourse related to the NDH legacy has continued. In October 1993 the Croatian Parliament passed an addition to the law regarding the pension system. Accordingly, those who served in the NDH military were granted an appropriate pension relative to their time spent in service during the war, or in custody after the war. ${ }^{15}$ This act was controversial, although not unique. In Yugoslavia the pensions were provided for the antifascist (Partisan) fighters from WWII and this practice has continued in Croatia. Instead of questioning the inherited Yugoslav pension system, the new addition to the law equalized all fighters in WWII irrespective of the side they were fighting for. This controversial legal move, as said, is not unique, since it could be found in Germany that provides pension rights to their former Nazis with war disabilities, including convicted war criminals, as well

14 See, in Croatian: https://www.slobodnadalmacija.hr/novosti/hrvatska/clanak/id/533734/evosto-je-franjo-tuman-govorio-o-hos-u-i-ustaskim-simbolima.

15 See: Zakon o dopunama Zakona o mirovinskom i invalidskom osiguranju. The link to the official document in Croatian: https://narodne-novine.nn.hr/clanci/sluzbeni/1993_10_96_1883.html. 
as to foreign volunteers like those from the Spanish fascist Blue Division that were fighting hand in hand with the Nazis. ${ }^{16}$ However, this was not the only controversy regarding the Croatian pension system here. Actually, at the level of semantics, this pension law named the NDH forces the Homeland Army (Domovinska vojska). Therefore, such legal discourse basically linked the concept of "homeland" that became a synonym for Croatia in the 1990s and allowed for the NDH forces to appropriate the same concept used for designating the Croatian war for independence known as the Homeland War.

Furthermore, in 1996, in the light of Tuđman's ongoing memory politics of national reconciliation, another confusing message was sent to the public when "the Remembrance Day for Croatian Victims in the Struggle for Freedom and Independence (Dan spomena na hrvatske žrtve u borbi za slobodu i nezavisnost)" (Pavlaković et al., 2018: 12) was linked to the Bleiburg commemoration. While massive killings of the surrendered people (soldiers and civilians) around the Austrian town of Bleiburg can be viewed as the hallmark of the Yugoslav Army's retaliations, and along with the Way of the Cross, the paradigm of communist mass violations of human rights, it is questionable to link these victims with the freedom fighters due to the discredited nature of the political entity they were fighting for. For Tuđman it was enough to view the warring sides as having legitimate aspirations for freedom and self-determination, regardless of the fact that he emphasized earlier (during the $1^{\text {st }}$ General Assembly of the HDZ in 1989) that the NDH was a "fascist crime". ${ }^{17}$ Indeed, the aspirations of Croats to have their own nation-state were legitimate, but these legitimate aspirations do not deny the fascist character of that state. Therefore, Tuđman's memory politics regarding naming the Bleiburg commemoration day as the one that should remind the Croatian people of their freedom fighters further confuses the official founding narrative. Namely, if the NDH military can be semantically equalized with the Croatian antifascists, or if those victims were basically labeled as freedom fighters for Croatian statehood, then it is highly confusing how the antifascist fighters and their ZAVNOH legacy have been enunciated as one of the founding premises of contemporary Croatia as it is outlined in the Historical Foundations of the Croatian Constitution. If the NDH was "a fascist crime", than its legal order that was embedding terror as its modus operandi, discredited those aspirations for Croatian statehood. In other words, if those aspirations were tainted, if they were, due to particular historical conditions, bounded in

${ }^{16}$ For more about this: https://www.nytimes.com/1997/05/10/world/germany-defends-pensionsfor-ss-veterans.html, and https:/www.telegraph.co.uk/news/worldnews/europe/spain/11994794/ Spains-Nazi-volunteers-defend-their-right-to-recognition-and-German-pensions.html.

17 In an interview given to the German Tageszeitung in July 1990, Tuđman said: "Croats fought for freedom under different flags" (Milekic, 2017). 
fascist methods and racial legal system, than any semantic and legal flirting with the NDH legacy of that sort further aggravates social divisions and relegates facing this difficult part of Croatian historical memory. Unfortunately, the victims of communist terror and its commemoration were occasionally exploited to tacitly sensitize the public, or sometimes even to glorify the NDH project.

Recent outbursts of memory wars that were boiled down to the social disputes related to the usage of For the Homeland Ready salute/insignia as well as, to a degree, to the five-pointed red star controversy, reflect the inability of Croatia to face its past openly and without deliberate confusions. Due to an ever-present political unwillingness to deal with these controversial symbolic expressions, the social confusions have intensified over the last decade, especially after a couple of incidents at football stadiums and concerts. Therefore, the salute/insignia For the Homeland Ready, whose criminalization has been required by some political actors and social groups, became the most controversial issue in Croatian memory wars. Such confused memory politics yielded a fractured society ${ }^{18}$ with numerous mnemonic actors willing to politicize memories and traumatic history. Symbolic expressions became a battleground for political reevaluation of the past, and various mnemonic warriors have started to deepen already existing confusions and social tensions regarding two failed pre-1990s political projects. This led to various controversial assessments and judgments regarding the legality and legitimacy of using symbolic expressions, as I have shown elsewhere (Cvijanović, 2016). ${ }^{19}$ For all these reasons the government decided to adopt a systematic approach toward the politics of memory, yet not without further confusions and controversies.

\section{Facing Communism: Dialogue Document as the Anti-Communist Manifesto}

In response to numerous political and civic initiatives for providing a framework for dealing with legal ambiguities regarding symbolic expressions and difficult memories, in 2017 the Croatian government established the Council for Dealing with the Consequences of Undemocratic Regimes, a kind of "truth commission" aiming to provide a document that would serve as a beckon in contemporary wastelands of Croatian legal and political confusions how to handle difficult memories and their symbolic projections. The Council was perceived, however, not just as a body that would carve a way out of legal inconsistencies and confusions in approaching the

${ }^{18}$ Or "regime", according to Bernhard and Kubik. They argue that after the fall of communism the post-communist regimes became predominantly either fractured, namely characterized with strong mnemonic cleavages, or unified regimes (Bernhard and Kubik, 2014).

${ }^{19}$ Available in Croatian only. 
disputed symbols and salutes that were polarizing society while being regularly politicized predominantly in relations to the veteran population, but moreover as an attempt at renewing national dialogue about the past, as a step toward new politics of reconciliation. Predominantly made of numerous experts in the field of law, history, and political science, the Council's purpose was to draft, on the one hand, a frame for the government's memory politics that would contain comprehensive recommendations aimed at facing the "difficult past" that would include shaping the educational curricula, dealing with controversial anniversaries such as commemorations, providing a framework for the politics of public space (i.e. the politics of naming and renaming streets, squares, etc., and moving or removing the monuments of those understood to be controversial political figures from the past), and on the other hand, similar clear-cut recommendations for regulating the use of insignia and symbols related to undemocratic regimes. The Council, however, cautiously articulated that its mission was not to rank "totalitarian repression of single phases of those regimes which were subject to change, but to deal with those practices and meanings the consequences of which may be felt today, and which are sometimes even positively evoked by certain political groups, thus causing conflicts which disturb citizens and spread hatred" (Dialogue Document, 2018: 1). ${ }^{20}$ By doing that, the Council adopted a wary as well as inconsistent interpretive approach in evaluating historical memories and symbolic expressions, hence yielding incoherent assessments and conclusions that can hardly reduce disputes about historical memory in Croatia.

The Dialogue Document is twofold: on the one hand, it provides a narrative about Croatian experiences with both totalitarian traumas - fascist and communist - of the $20^{\text {th }}$ century, and on the other hand, it aspires to serve as a declaratory memory law with prescriptions aiming "to confer solemnity upon a brutal past" (Heinze, 2017: 417), although not purely declaratory since its recommendations might yield punitive regulatory actions if integrated in the legal system. ${ }^{21}$ This has been clear from its subtitle: Postulates and Recommendations - On Specific Normative Regulation of Symbols, Emblems and other Insignia of Totalitarian Regimes

${ }^{20}$ It is interesting to note that the Council identified the origins of fascist terror in the monarchist Yugoslavia prior to WWII: "The first fascist organization in the Kingdom of Slovenes, Croats and Serbs, more precisely in Croatia, was the Yugoslav Progressive Nationalist Youth/Organization of Yugoslav nationalists (ORJUNA), founded in 1921 as a pro-regime, monarchist and unitarianist organisation that terrorized and even assassinated Croatian patriots and workers' rights advocates" (Dialogue Document, 2018: 3).

${ }^{21}$ For detailed and instructive distinctions between declaratory non-regulatory memory laws on the one hand, and regulatory memory laws that might be non-punitive or punitive on the other, see: Heinze, 2017. 
and Movements. ${ }^{22}$ What draws attention from the beginning is a sort of disclaimer that the Dialogue Document makes when approaching the memories of fascist and communist crimes. For the creators of the Document it was important to emphasize in its foundational postulates "an asymmetry between well-known fascist crimes which were publicly condemned and long covered up and less investigated communist crimes" (Dialogue Document, 2018: 5). According to my view, this assessment becomes important since it possibly explains the whole narrative regarding the crimes of undemocratic regimes focused on the communist terror. Instead of fair and proportionate descriptions of fascist and communist state-sponsored politics of terror, the role of political leaders of these regimes in supporting legal framework and repressive apparatus that led to gross violations of human rights, we have confusing and imbalanced dealings with history, memory, and symbols. On the one hand, the Document outlines the responsibility of the communist regime in undermining antifascism to an extent by "converting it into an ideologeme under the guise of which mass crimes and human rights violations were committed", and states that occasional "misuse of antifascism" is "aimed at discrediting political opponents and in some cases to negate or criminalise Croatia's statehood and independence that was won in the Homeland War" (ibid.: 4-5). This assessment obviously only partially deals with the communist past, but rather points toward the ghoul of communism that has been cloaked in antifascism and as such is portrayed as an ever-present danger for the Croatian state. Such a message is again confusing at the very least, if not problematic, since antifascism is not necessarily linked with communism. But even if the Document targets such "antifascist" tendencies that were attempting to discredit contemporary "Croatia's statehood and independence that was won in the Homeland War", it is far from clear, based on these vague statements, who should be targeted and for what reasons in particular. On the other hand, there were no similar accounts about what the Independent State of Croatia $(\mathrm{NDH})$ is responsible for in relation to cultural trauma. Actually, the NDH was acknowledged only as a political entity opposed to the fundaments of the Croatian Constitution, but the Document is silent regarding particular crimes of that regime, as well as about possible discrediting of "Croatia's statehood and independence that was won in the Homeland War" due to proliferation in popular use of the Ustasha insignia and salutes under the guise of readopting an old pre-WWII Croatian tradition, or due to the fact that these insignia were part of the Homeland War legacy.

For those reasons the flaw of the Document's foundational postulates is in the narrative that is not only biased in evaluating both regimes, but also revisionist in a

${ }^{22}$ For the English version of the Dialogue Document, see: https://vlada.gov.hr/UserDocsImages//Vijesti/2018/05\%20svibanj/5\%20svibnja//DOKUMENT\%20DIJALOGA\%20ENG.pdf (retrieved 8 October 2018). 
sense that there were no genuine attempts to discuss fascist crimes. The irony is that these crimes are only generally implied in the statement about communist crimes in the sentence stating how "serious crimes and human rights violations were also committed during the communist rule..." (ibid.: 5, my emphasis), so the reader might assume that there were other crimes prior to the era of communist terror. If an alien were to read the Document, he would have the impression that only the crimes of communism really matter, since the reader is unable to get any information from the text about a single fascist crime. While the Document correctly and clearly names particular communist crimes such as the "Bleiburg tragedy" and the "all-powerful communist repressive police apparatus" that committed grave crimes against humanity through its "bloody reprisals against the Catholic Church and peasants ('kulaks'), confiscation of property and persecution of the 'class enemy' and political opponents", including their own "Party members during the purges of 'cominformists' (Goli otok)"23 (ibid.: 4), at the same time fascist crimes are veiled with a "deafening silence". ${ }^{24}$ Communist terror and its crimes in the aftermath of WWII as well as in the following decades were large-scale crimes against humanity by definition. However, by being silent about the NDH racial laws that enabled the whole spectra of state-sponsored terror (repression, mass executions, deportations, etc.) against the "blacklisted" minorities (Jews, Serbs, and the Roma people, among all), by ignoring to mention explicitly the horrors of the concentration camps in the NDH - by not even mentioning "Jasenovac as the most prominent substantive and symbolic expression of that creation" (Kasapović, 2018: 11) - the Document not only fails in its opportunity to seriously confront Croatian society with its difficult past, except only in a declaratory fashion and in general terms, but also leaves an aura of revisionism in the air. ${ }^{25}$ It does not mean that the Document denies these horrors, but at the very least, if not deliberately, it willy-nilly reboots collective memories by allowing for

${ }^{23}$ Goli otok is the name of the Croatian island that had served first as a political prison and labor camp for alleged Stalinists (after a while also for regular prisoners), so in the public discourse it is also used as a metaphor for communist terror.

24 Page uses the term "deafening silence" as an inadequate "typical response to the fascist past" pointing at the presence of Mussolini's heritage in Italy, both in terms of architecture as well as political life (Page, 2016: 134-140).

${ }^{25}$ In his dissenting opinion on the Dialogue Document, Željko Tanjić puts forward an ironic statement that we could "admire the Croatian Constitution that discarded the NDH despite historical aspirations of the Croatian people for a free and independent state". It is not clear to whom this "complaint" has been addressed, but it seems that it targets those "founding fathers" of the Croatian Constitution, more particularly Franjo Tuđman as the author of its Historical Foundations. See: Dissenting opinion on the Dialogue Document by Željko Tanjić, available in Croatian only at the following link: https:/vlada.gov.hr/UserDocsImages/Vijesti/2018/02\%20 veljača/28\%20veljače/Mišljenje\%20prof.\%20dr.\%20sc.\%20Željka\%20Tanjića.pdf. 
their absence. In that sense, the foundational postulates of the Document sound more like an anti-communist manifesto than a fair assessment of both totalitarian terrors. The Council's justification is that unlike fascist crimes, "the issues of crimes and victims of communist regimes (globally and in Croatia) remain ambiguous or at least unexplored, leaving the possibility of further antagonism within society" (Dialogue Document, 2018: 15). However, as the French philosopher Merleau-Ponty said: "The absence of a sign can be a sign" (Merleau-Ponty, 1964: 44). Here, the silence is a sign that the Document's foundations are deeply compromised and thus flawed.

\section{Stars and Salutes: Dialogue Document and Disputed Symbolic Expressions}

The Document's interpretative reflections about the origins of memory wars in Croatia represent the basis for recommendations for potential legal penalties related to public use of controversial symbols and symbolic expressions. Accordingly, the Council inquired into differentiating among symbols and their meanings, yet not only those related to the period of communist and fascist rule, but also those from the Homeland War and the armed aggression against Croatia in the 1990s. So, what is the Council's take on symbols and symbolic expressions? There are a few general problems regarding symbols that the Dialogue Document wants to address:

a) relationship between symbolic expressions and freedom of speech;

b) differing between intentions of symbolic expressions;

c) classifying symbolic expressions according to their meanings;

d) exceptions from punitive regulations.

The Council's overall view implicates that not all symbols of hate are created equal. On the one hand, this view draws on the judgment of the European Court of Human Rights (ECtHR, or the Court) related to the five-pointed red star case, the issue that divides not only Croatia, but Europe as well. On the other hand, when discussing the most controversial symbolic expression in recent Croatian memory wars - For the Homeland Ready salute - concessions are made for the sake of "the necessity of balancing" (Dialogue Document, 2018: 27). Let me go through the outlined points in order to address these controversial conclusions that not only made no difference in leveling social divisions, but had actually riven the Council itself by yielding various dissenting opinions. This has shown that there is a deep social divide not only in relation to the difficult past, but also in the way in which memory politics should be approached.

First, the Dialogue Document relies on international and domestic legal frameworks when discussing freedoms and their limitations regarding symbolic expression. Quoting the Court's interpretation of the European Convention on Human 
Rights, it is said that "freedom of expression constitutes one of the essential foundations of a democratic society" and that "it is applicable not only to 'information' or 'ideas' that are favourably received or regarded as inoffensive or as a matter of indifference, but also to those that offend, shock or disturb"; but, as "set forth in Article 10, freedom of expression is subject to exceptions, which must, however, be construed strictly, and the need for any restrictions must be established convincingly" (ibid.: 9). It is understood that these restrictions are outlined in Article 39 of the Croatian Constitution that bans incitement to war or use of violence as well as any call for hatred or intolerance, and that these provisions have been enacted into the Criminal Code under Article 325 that sanctions hatred and intolerance, as well as under Article 235 that prescribes punitive measures for anyone "who publicly approves of, denies or grossly trivialises the crimes of genocide, crimes of aggression, crimes against humanity or war crimes directed against a group of persons or a member of such a group on account of their race, religion, national or ethnic origin, descent or colour, in a manner likely to incite to violence or hatred against such a group or a member of such a group" (ibid.: 7). While these legal articulations belong to the standard language of human rights and protections against violence, intolerance, and discrimination based on someone's identity features, the problem appears in interpreting symbolic expressions, namely when the Council starts to weigh between intentions of various symbolic expressions without grounding its view explicitly. Without providing any clue of what the Council has in mind, the Document says that some symbolic expressions might be taken "as a provocation", while others as those that commemorate "tragic events from the past", hence those being provocative could be sanctioned "in the context of disturbing the public order and peace or disturbing citizens" (ibid.: 14). Although it is not explicitly stated, this view leans on the Croatian Misdemeanor Act on Public Order and Peace, specifically Article 1 that prohibits disturbing public order and peace in a very broad and vague sense (i.e. all behavior that yields unrest, indisposition, uneasiness, insults public morality, etc.) and as such having detrimental outcomes for free speech (Cvijanović, 2016: 100-101). On top of that, along with the vagueness of the legislative framework, the Document's proposal is basically in conflict with its previous endorsement of those provisions from Article 10 of the European Convention according to which public expressions might be offensive, shocking, and disturbing for some people. Furthermore, it would be hardly possible to reach a broader consensus about what has to be considered offensive or disturbing in the context of highly polarized views about certain symbolic expressions and memories. For example, waving the red star symbol as well as having a public celebration of Tito's birthday can be viewed as a provocation along with glorification, as it would probably be if someone wore the red star in a church. Also, in that context, what symbolic expressions would fit commemoration of victims of the Bleiburg tragedy and 
the Way of the Cross, if any? Finally, what should be done when provocations might involve coded symbols, namely those not recognized by the legislator, or the general public, but the particular group that has been targeted?

Accepting the view that not all symbols are created equal, namely that there is presupposed inequality among symbols grounded in their meanings, the Council attempted to differentiate between inherent meanings of controversial symbolic expressions termed "disputed insignia of hate" that belong to "totalitarian regimes or movements", namely "fascism (including National Socialism, the Ustasha movement, and the Chetnik movement) and communism" (Dialogue Document, 2018: 19). In order to make any differentiation between meanings possible, the Council adopted a terminology of ambiguous versus unambiguous symbolic expressions that have been used in recent European jurisprudence. However, it turns out that applying this differentiation in the Document is incoherent and inconsistent, and hence questionable for carving out any legal outcomes based on these recommendations.

First of all, we should be aware that any ambition to single out unambiguous from ambiguous symbolic representations would be at odds with the multiple meanings/ambiguousness argument if we take semiotics and symbolism seriously. According to Cohen, "symbols are objects, acts, relationships or linguistic formations that stand ambiguously for a multiplicity of meanings, evoke emotions, and impel men to action" (Cohen, 1976: 23). Therefore, one of the most important features of a symbol is that it "holds different meanings to different persons and to the same person at different times" (ibid.: 24). It means that, for example, the German Iron Cross can be used as the German military symbol, but also might be perceived as a symbol being part of the official Nazi insignia during WWII along with the swastika. The fact that every symbol generates culture-specific meaning, i.e. not literal (denotative) but various connotative meanings shaped through particular time and space is the very property of a symbol. Symbolic expressions gain their meaning through particular culture, through connotation, they communicate meanings in such ways that these meanings are not fixed, but depend on socially established agreement. As Berger put it: "Semiotically speaking, symbols are things with important historical and cultural meaning" (Berger, 2010: 14). Hence we talk about cultural symbols. If there is a disagreement about the meaning of symbolic expressions, we have socially contentious symbols. Thus, the whole argument that there is a dividing line between ambiguous and unambiguous symbols and that this division is immune to the changes in perception of a symbol over time, that the meaning can be fixed, is semiotically flawed.

However, according to the Council's proposition, disputed insignia that should be deemed unambiguous, called also "prima facie disputed insignia of hate", are qualified that way "because they are created precisely to identify the regimes and movements they belong to" and "their criminal and genocide policy" among all, and 
as a result are assigned to "the insignia of fascism in all its manifestations" (Dialogue Document, 2018: 22-23). As for ambiguous insignia of hate, it is argued that they hold multiple meanings, in other words their meanings have a shape-shifting property, so they can take either legitimate or illegitimate shape.

In the context of the European jurisprudence, the multiple meanings argument was linked notably to the five-pointed red star controversy, also known as the Vajnai v. Hungary (2008) case. Actually, the case was dealing with freedom of speech, but it became paradigmatic because of the multiple meanings argument that has been occasionally cited in the Croatian context, as well as in the Council's Document. According to Hungary's legal regulations regarding the use of totalitarian symbols (Article 269B), the use of the five-pointed red star in public was forbidden along with other totalitarian symbols such as the swastika, the SS insignia, the arrowcross, and the hammer and sickle. So after the Hungarian applicant in this case was convicted for wearing totalitarian symbols during demonstrations, the case ended up in the European Court (ECtHR). It decided that the five-pointed red star contains multiple meanings: it is viewed as a totalitarian symbol related to the era of communism and its "mass violations of human rights" that indeed "discredited the symbolic value of the red star", ${ }^{26}$ however it is also argued that this symbol has been used legitimately and legally in various political organizations - from the international workers' movement to various political parties. The ECtHR acknowledged that this symbol might be disrespectful and could "create uneasiness amongst past victims and their relatives", but curbing freedom of speech in the name of protecting someone's state of mind was considered unacceptable since "a legal system which applies restrictions on human rights in order to satisfy the dictates of public feeling - real or imaginary - cannot be regarded as meeting the pressing social needs recognized in a democratic society, since that society must remain reasonable in its judgment" ${ }^{27}$ From the Croatian perspective, however, this judgment is in discrepancy with all-inclusive punitive provisions of the Croatian Misdemeanor Act on Public Order and Peace, specifically Article 1 that, as I mentioned earlier, is in favor of protecting public feelings by penalizing acts that might cause "uneasiness" among the public, and not in favor of protecting freedom of speech as outlined. ${ }^{28}$

26 Vajnai v. Hungary, ECtHR (2008), para. 52. I discussed this case as well earlier in: Cvijanović, 2016. Also, for a more detailed account of this case relevant for the discussion regarding the problem of regulating symbolic expressions, see Gardašević's article in this collection.

27 Vajnai v. Hungary, ECtHR (2008), para. 57.

28 This explanation of the ECtHR can be compared to the decision of the American Supreme Court in the case Cohen v. California (1971) in which the speaker is defined as the one who determines the content of the speech, not the government that cannot act as a guardian of public morality, as I have discussed in Cvijanović, 2016. 
Following the Vajnai case the ECtHR repeated the multiple meanings argument related to the disputed symbol in Fáber v. Hungary (2012). The case is interesting since the applicant was holding the Hungarian Árpád flag that has been disputed as the flag that resembled the flag of the Arrow Cross Party during WWII known as the Nazi collaborators responsible for mass executions and deportations of Jews and Roma people. The police approached the applicant to remove the flag or leave the site close to the place where massive exterminations of Jews were happening during WWII by the Arrow Cross regime, the site that was picked for these symbolic reasons for the Hungarian Socialist Party's (MSZP) rally against racism and hatred. The Hungarian domestic courts penalized the applicant based on the view that the applicant was "disturbing public tranquility" since "the display was capable of causing public disorder". ${ }^{29}$ However, the ECtHR dismissed this argument. The applicant opposed to the domestic court's view that "the use of the flag had been harmful of provocative", claiming also that the flag has been considered historical and "not being a totalitarian or banned symbol under Hungarian law", so its use could not indicate "any potential or actual hostility or aggression either". ${ }^{30}$ The ECtHR protected freedom of speech as well as freedom of assembly even though the provocative flag was displayed close to the site of piety, arguing that "the display of a symbol associated with a political movement or entity, like that of a flag, is capable of expressing identification with ideas or representing them and falls within the ambit of expression protected by Article 10 of the Convention. When the right to freedom of expression is exercised in the context of political speech through the use of symbols, utmost care must be observed in applying any restrictions, especially if the case involves symbols which have multiple meanings", and adding that "interfering with freedom of assembly and expression other than in cases of incitement to violence or rejection of democratic principles - however shocking and unacceptable certain views or words used may appear to the authorities - do a disservice to democracy and often even endanger it". ${ }^{31}$ It should be noted that in the Fáber case it is not perfectly clear how to interpret "rejection of democratic principles" since the Court obviously did not hold that displaying the disputed flag endangered these principles. Therefore, the ECtHR did not penalize the applicant even though his display of the Hungarian Árpád flag was viewed as "fascist" cialist Party members that were having a rally near the site of mass killings of Jews in WWII, as already mentioned. It is interesting that the Court did not find proble-

${ }^{29}$ Fáber v. Hungary, ECtHR (2012), para. 51 and para. 53. See also Gardašević's article in this collection.

30 Fáber v. Hungary, ECtHR (2012), para. 27.

31 Ibid., para. 36 and also para. 37.

32 Ibid., para. 52. 
matic having a counter-demonstration in the close vicinity of the site that is generally viewed as the site of piety; however, emphasizing that time and place matter when deciding about restricting controversial symbols with multiple meanings having in mind national memories and traumas:

The Court does not exclude that the display of a contextually ambiguous symbol at the specific site of mass murders may in certain circumstances express identification with the perpetrators of those crimes; it is for this reason that even otherwise protected expression is not equally permissible in all places and at all times. In certain countries with a traumatic historical experience comparable to that of Hungary, a ban on demonstrations - to be held on a specific day of remembrance - which are offensive to the memory of the victims of totalitarianism who perished at a given site may be considered to represent a pressing social need. The need to protect the rights to honour the murdered and the piety rights of their relatives may necessitate an interference with the right to freedom of expression, and it might be legitimate when the particular place and time of the otherwise protected expression unequivocally changes the meaning of a certain display. Similar considerations apply if the expression, because of its timing and place, amounts to the glorification of war crimes, crimes against humanity or genocide (see Garaudy v. France (dec.), no. 65831/01, ECHR2003-IX (extracts)). Moreover, where the applicant expresses contempt for the victims of a totalitarian regime as such, this may amount - in application of Article 17 of the Convention - to an abuse of Convention rights (see Witzsch v. Germany (dec.), no. 41448/98, 20 April 1999). However, the Court is satisfied that in the instant case no such abusive element can be identified. ${ }^{33}$

The ECtHR related this case to the Vajnai case in which the ban of the red star as "a symbol used by a totalitarian regime in Hungary" is viewed problematic since it would "set the limits of freedom of expression" that were solely based on the sentiments that this symbol induces in the public. ${ }^{34}$ Based on both adjudications in the cases mentioned, the ECtHR was in favor of protecting freedom of speech and freedom of assembly, hence allowing for the display of contentious symbolic expressions whose restrictions regarding the commemorative events and the sights of piety has to be strictly confined to particular "time and place", for example "a specific day of remembrance". ${ }^{35}$ In that sense, the Court's adjudications resemble the American Supreme Court's juridical practice in its defense of freedom of speech by flirting with "viewpoint neutrality and inadmissibility of content-based restrictions" (Belavusau, 2013: 47) that disallows discrimination among symbolic expres-

${ }^{33}$ Ibid., para. 58.

${ }^{34}$ Ibid., para. 57 (also see Vajnai, para. 57).

${ }^{35}$ Ibid., para. 58. 
sions, as one of the concurring opinions in the Fáber case notified too, stating that the Court's approach is "if a left wing political symbol is allowed, irrespective of the consequences that its exposing may produce, then a right wing symbol should be allowed as well". ${ }^{36}$

However, the advocates of the bans would claim that freedom of speech should be taken secondary when disputed symbolic expressions are at stake since these aggravate cultural trauma, yield fractured society with deep socio-political cleavages, and hence could be detrimental for national reconciliation. From this point of view, it is problematic that protecting freedom of speech invalidates the argument that certain disputed symbols can be linked with the regimes that were deliberately using these symbolic expressions to systematically violate human rights to the highest proportions. Namely, even though the ECtHR as well as the Dialogue Document condemn the communist totalitarian terror, and emphasize that as a result of its crimes against humanity the five-pointed red star symbol has been discredited, as it is claimed in the Vajnai case, it is concluded that this symbol carries a positive meaning too. Regardless of this line of arguing, due to the fact that society is deeply polarized in this case, the five-pointed red star controversy can be seen as the wittgensteinian "rabbit-duck illusion" - either you view it as a positive or negative symbol; it cannot be both at the same time. The ECtHR's explanation is questionable since its assessment is backed-up, among all, with a claim that "there is no evidence to suggest that there is a real and present danger of any political movement or party restoring the communist dictatorship" and adding that the "Government have not shown the existence of such a threat prior to the enactment of the ban in question". ${ }^{37}$ This explanation is flawed since it, misguidedly, invokes the "real and present danger" test or a "threat" argument that would legitimize any immediate ban, while this issue has nothing to do with the purpose of a possible ban which can be viewed as symbolic prohibition of a symbol that has been inflaming memory wars. If, however, we applied the "real and present danger" test in this case as well as in the case of displaying any fascist symbol, then it would be difficult to prove the existence of such danger in democracies aside from a possibility for incitement of violence in very controlled conditions. In addition, the "real and present danger" test can be misguidedly used as an argument in favor of banning communist symbols (along with fascist symbols), but there is no real danger of restoring communism (or fascism) in these societies, so the argument of that sort is flawed. Rather, any meaningful ban, if there is such, should be based on the demands for historical justice and memories, so the injuries from the past could not be relativized. If the ECtHR ar-

${ }^{36}$ Concurring opinion of judge Popović joined by judge Berro-Lefèvre, in: Fáber v. Hungary, ECtHR (2012), p. 26.

${ }^{37}$ Vajnai v. Hungary, ECtHR (2008), para. 49. 
gued that "serious crimes had been committed by the security forces of totalitarian regimes, whose official symbols included the red star", ${ }^{38}$ it is highly dubious how it came to the following conclusion: "These violations of human rights could not, however, discredit the ideology of communism as such, let alone challenge the political values symbolised by the red star." ${ }^{39}$ Some could not only argue that the very communist ideology presupposes violations of human rights through its revolutionary program and strategy whose goal was, among all, violent "abolition of bourgeois property" (Marx \& Engels, 1978: 486), but such official statements create a perception about double standards in judging totalitarian regimes. Namely, it seems that not all crimes were treated equal when facing the consequences of totalitarian regimes, that eradication of the class enemy, the enemy of the people, or the enemy of the revolution (including their own members) is not perceived the same as eradication of the racial enemy.

However, it should be pointed out that, unlike the European Court's vindication of symbolic expression that has been discredited, the Slovenian Constitutional Court did not disregard the burden of comparable discredited symbolic expression, as it was the case with the ECtHR. Namely, in the case of street naming and renaming, the Slovenian Constitutional Court acknowledged the multiple meanings argument, but decided not to draw the same conclusions as the ECtHR. In other words, the multiple meanings argument is not viewed as an argument that can be used to prohibit banning a controversial symbol if this symbol can be in any way associated with the crimes against humanity, because this would be enough to discredit the public use of controversial symbolic expression. Specifically, the Slovenian Constitutional Court banned Tito's name for the street in the Slovenian capital claiming that his antifascism is not sufficient for vindicating his communist repressive regime and him as a symbol of that regime. The court argued:

The name Tito does not only symbolize the liberation of the territory of presentday Slovenia from the Fascist occupation in World War II, as alleged by the opposing party, it also symbolises the post-war totalitarian communist regime, which was marked by extensive and gross violations of human rights and fundamental freedoms, especially in the decade directly following World War II... The fact that Josip Broz Tito was the leader of the former state entails that it is precisely his name that to the greatest extent symbolises the former totalitarian regime. Tito's symbolic significance cannot be divided such that only the significance of the actions that the opposing party attributes to his historical role and personality are considered. Once again naming a street after Josip Broz Tito, who is a symbol of the Yugoslav communist regime, can be understood as support not only for him

38 Ibid., para. 37.

39 Ibid. 
as a historical figure or his individual actions, but also as support for the entire historical period of his rule and for his rule as such. Therefore, it is not important what the municipal authority wished to achieve by introducing Tito Street or which objectives it pursued; it is important that the challenged Ordinance must objectively be understood as a form of recognition conferred on the former undemocratic regime..$^{40}$

The Slovenian case shows that if multiple meaning is at stake, it does not necessarily yield impossibility for banning a symbol in question just because this symbol can be linked with something positive - the fact that Tito was a leader of the antifascist Partisan movement. Rather, the Court held that terror and all other serious injuries of human rights committed under Tito's rule after the war discredited all the positive meanings of his leadership, and cannot be disregarded in that sense.

While the foundational postulates of the Croatian Dialogue Document are vehement in condemning the communist violations of human rights, the Council did not draw any conclusion similar to the Slovenian case. It decided to support the initial terminology of ambiguous versus unambiguous insignia. So, what are the elements that led to such inconsistent and unconvincing Council's recommendations? First, even though the communist crimes were committed under the red star symbol, because the Partisan movement was fighting against fascism under that symbol, the Council did not suggest a blanket ban following the multiple meanings argument in the Vajnai case. As we can see from the Slovenian case, the Council could adopt a more decisive view and ban those symbolic expressions of the antifascist legacy that can be linked to the communist terror and its violations of human rights. In fact, in one of the dissenting opinions it was argued that this imbalanced double-standard approach of the Council that relies on "the practice of the Western EU countries" disregards particular Croatian historical memories and thus enhances "the old leftist thesis that communism, regardless of its totalitarian shortcomings, is nonetheless more acceptable than fascism". ${ }^{41}$ Additional dissenting opinions were also focused on the incoherencies within the Document claiming that communist symbolic expressions - the five-pointed red star, the sickle and hammer, and the salute Death

40 Slovenian Constitutional Court case-law on The Ordinance on Determining and Changing the Names and Course of the Roads and Streets in the Territory of Ljubljana Municipality (Official Gazette RS, No. 44/09), Article 2, see: http://odlocitve.us-rs.si/en/odlocitev/AN03530?q=u-i$109 \% 2 \mathrm{~F} 10$.

${ }_{11}$ Dissenting opinion on the Dialogue Document by Željko Tanjić, available in Croatian at: https://vlada.gov.hr/UserDocsImages/Vijesti/2018/02\%20veljača/28\%20veljače/Mišljenje\%20 prof.\%20dr.\%20sc.\%20Željka\%20Tanjića.pdf. 
to Fascism, Freedom to the People - have to be put on an equal footing with other prima facie symbols of hate. ${ }^{42}$

Besides, the red star controversy in Croatia is further complicated since it is related to recent memories from the Homeland War. Unlike many other European cases, Croatia has its own peculiarities - the trauma of the Homeland War and the crimes committed by the Yugoslav military and Serbian paramilitary forces - that, on top of the communism/fascism divide, additionally triggers memory wars. Since the Council argued that "possible blanket prohibitions could also focus on the insignia of the aggressors' armed forces operating in certain parts of the Croatian state territory from 1991 to 1995" (Dialogue Document, 2018: 27), this implies legitimate banning of the five-pointed red star when related to the aggressors' insignia, i.e. as a symbol of the Yugoslav Army - it was on the helmets, uniforms, planes, vehicles, etc. This conclusion adds to the multiple meanings argument suggesting that the five-pointed red star is only viewed as disturbing for many people due to its connections to the communist terror, but also due to the fact that it has been additionally discredited by the Yugoslav Army and their crimes against humanity during the Homeland War. However, since the Council's vindication of the five-pointed red star prevents from taking seriously any suggested blanket bans of the aggressors' insignia of the same sort, the Council's recommendations are inconsistent, and the Document is thus incoherent regarding the status and the use of the five-pointed red star as a symbol of antifascism, of communist terror, and also of the aggressors in the 1990s. While, according to the Council, "it would not be unacceptable to explicitly prohibit their public use" (ibid.: 26), the Document did not pursue to draft the ways in which this would be possible for ambiguous disputed insignia, since, due to their ambiguousness, these symbols were excluded from possible blanket bans. Regarding the aggressor's insignia, aside from the Chetnik cockade that is listed as a prima facie symbol of hate, any other possible suggestion to add other symbols that can be semiotically linked to the aggressors has not be discussed at all. For example, in a similar way the letter $U$ has been used as graffiti from the 1990s on, the four C's in Cyrillic were used as a symbol that many would link to the war trauma

${ }^{42}$ Dissenting opinion on the Dialogue Document by Mladen Ančić, Nataša Jovičić, Ivo Lučin, Ante Nazor, and Nevio Šetić, available in Croatian at: https://vlada.gov.hr/UserDocsImages/Vijesti/2018/02\%20veljača/28\%20veljače/Mišljenja\%20prof.\%20dr.\%20sc.\%20Mladena\%20Ančića\%2c\%20Nataše\%20Jovičić\%2c\%20dr.\%20sc.\%20Ive\%20Lučića\%2c\%20doc.\% 20dr.\%20sc.\%20Ante\%20Nazora\%20i\%20prof.\%20dr.\%20sc.\%20Nevija\%20Šetića.pdf. In his dissenting opinion Ivan Savić adds that if Croatia decided to ban the five-pointed red star, or the sickle and hammer, this would be similar to the legal steps made by Lithuania and Hungary. See: Dissenting opinion on the Dialogue Document by Ivan Savić, available in Croatian at: https://vlada.gov.hr/UserDocsImages/Vijesti/2018/02\%20veljača/28\%20veljače/Dopunsko\%20 mišljenje\%20doc.\%20dr.\%20sc.\%20Vanja-Ivan\%20Savić.pdf. 
and aggression. While the first mentioned symbol is considered a prima facie symbol of hate, the other belongs to officially recognized Serbian heraldic. However, the trauma might be the same since these symbols generated their meanings through specific historical circumstances. In that context even the Cyrillic letters on the official town panels were targeted and damaged due to the politicization of trauma.

But the most controversial issue, and as such even more confusing, is the Council's evaluation of the salute For the Homeland Ready. Controversy behind that salute has been propelling social divisions and leading to numerous public incidents where the use of this salute, either as part of the military insignia, or as a sort of provocation, a right-wing folklore, or resistance to the dominant political culture, has been confusing the public and the state officials - the courts and the police predominantly - since there are no explicit prohibitions in the Croatian legal system from using that salute. ${ }^{43}$ Various interpretations about the origin of the salute, or about its legitimacy have spurred growing social divisions, and the whole thing became a matter of politicization, especially in relation to the veterans of the Homeland War. One way of interpreting is the claim that this is an old Croatian salute, another that it is the Ustasha salute, and the third that it was originally the Ustasha salute but in the context of the Homeland War (predominantly as insignia of the HOS fighters, and/or a feature of M. P. Thompson's song Bojna Čavoglave (The Čavoglave Battalion ${ }^{44}$ )) it acquired new meaning. In the fall of 2017, a few months prior to the release of the Document, the Croatian president Kolinda Grabar-Kitarović said in a TV interview, while answering the question about the salute For the Homeland Ready, that it is an old Croatian salute, yet emphasizing that she is not a historian. But Croatian politician (as well as historian) Zlatko Hasanbegović, perceived in the public as a prominent political figure coming from the right-wing political spectrum, denied that the salute For the Homeland Ready can be legitimized that way: "I have never claimed that this is an old Croatian salute. It's not. It is the Ustasha salute and this is why it is burdened. Except in one case only - when it is inside the coat of arms of the HOS under which that unit fought in the Homeland War." ${ }^{45}$ In a basically simi-

${ }^{43}$ For a more detailed account of the legislative and the use of the abovementioned salute, see again Cvijanović, 2016: 98-105.

44 The song is about the Croatian battalion defending the village Čavoglave during 1991, and it served for boosting the morale of Croatian soldiers and the people in general. The song was aired for the first time on 31 December 1991 during the Homeland War and has been perceived in the public either as patriotic, or controversial due to the fact that it starts with the salute For the Homeland Ready.

${ }^{45}$ For Hasanbegović, For the Homeland Ready can be prohibited if used exclusively as an instrument for incitement of hatred. Besides that he advocates no prohibition on any symbol. See: Hasanbegović predsjednici: Ne, "za dom spremni" nije stari hrvatski, nego ustaški pozdrav, in: Novi list, available at: http://www.novilist.hr/Vijesti/Hrvatska/HASANBEGOVIC-PREDSJED- 
lar way, the Council starts with the premise that the salute in question is indeed the Ustasha salute originally, but toward the end of the Document the argument becomes more ambivalent and invokes a possible exception from treating it as the Ustasha salute when used as insignia and for commemorative purposes. That makes the Document's statement confusing and inconsistent with its premises.

The Document is adamant in stating that "the insignia of fascism in all its manifestations" are "prima facie disputed insignia of hate [that] could be subject to a special regime of blanket prohibitions" and those, according to the Document, are: "the fascist Roman salute, the so-called Hitler salute accompanied by swastika, the Nazi 'SS' emblem, the Chetnik cockade, the Ustasha ' $U$ ', the Ustasha salute 'Za dom i poglavnika (For the homeland and its leader)' and 'Za dom spremni (For the homeland ready)"' (Dialogue Document, 2018: 23-25). But from the Council's premises according to which all fascist symbols are considered unambiguous and thus have to be prohibited, and the salute For the Homeland Ready is claimed to be a prima facie fascist symbol, it is hard to get to the conclusion that possible exceptions, or concessions, can be made to the proposed blanket prohibition of the salute in question. But there is an explanation for that incoherence in the Document. Namely, instead of facing us with the past the Council has to face us with the present: "we are faced with a particularly sensitive situation which arises from the direct conflict of, on the one hand, a prima facie disputed insignia of hate which the Constitution rejects, and on the other hand, the official tolerance of the unconstitutional practice of its public use on the insignia of a particular Croatian military unit...", and hence "the necessity of balancing" between the two (ibid.: 26-27, underlined by H. C.). ${ }^{46}$ This is another controversial and confusing statement. The

NICI-Ne-za-dom-spremni-nije-stari-hrvatski-nego-ustaski-pozdrav (retrieved 8 October 2018). Actually, a year before that statement, namely in September 2016, Hasanbegović had argued the claim that it was the Ustasha salute; https://net.hr/danas/hrvatska/hasanbegovic-postao-samikona-desnice-jer-me-napala-skupina-ideoloskih-uskogrudnika-svi-koji-me-poznaju-znaju-danisam-ekstremist/ (retrieved 8 October 2018).

46 In the footnote the Document here refers to the case France, Norway, Denmark, Sweden, Netherlands $v$. Turkey (1983) where the notion of "official tolerance" apparently appears in the context of tolerating torture in Turkey after the military coup and the emergency legislation. The European Commission was trying to figure out if Turkey tolerated violation of human rights at a lower level, not necessarily at a higher level due to the fact that there were political decisions from the top directed against these practices. We can find that depiction of "official tolerance" related to the Turkish case in the Yearbook of the European Convention on Human Rights (even though the Document does not mention any source, not even citing properly when necessary) that says: "though acts of torture or ill-treatment are plainly illegal, they are tolerated in the sense that the superiors of those immediately responsible, thought cognizant of such acts, take no action to punish them or to prevent their repetition; or that higher authority, in face of numerous allegations, manifests indifference by refusing any adequate investigation of their truth or falsity, 
concept of "official tolerance" was not only used to describe the practice in the 1990 s, but also as something that yields to "given" conditions in the contemporary context as a foundation for continuous concessions to be made related to the regulation of the disputed salute:

Due to the failure of the competent authorities, for more than a quarter of a century, this salute has been de facto and de lege (also) linked to the Homeland War, which today serves (also) as proof in social discussions that the meaning of the disputed salute, that originated in the Ustasha regime, became ambiguous because of its use in the context of the just and legitimate Homeland War (hence it should be singled out and subjected to the regime of ambiguous disputed insignia). This proposition is not acceptable because it does not take into account the fact that even during the Homeland War this salute was contrary to the Constitution, however there was a lack of a proper official response, thus today we are faced with this salute as given (ibid.: 26). ${ }^{47}$

As we can see, the Council refuses the argument that the salute can be converted from an unambiguous prima facie fascist symbol into an ambiguous symbolic expression, but at the same time it de facto acknowledges the ambiguous character of that symbolic expression in its very explanation of how the symbol has been perceived from the 1990s. The fact that this salute can be linked to the Homeland War's insignia irrespective of its Ustasha origin proves that this symbolic expression willy-nilly adopted an additional meaning. Since, regardless of its legal status, the salute can be related to the Homeland War, and later on with the insignia of veteran associations of the former HOS militia, the whole Council's effort to push for the unambiguous versus ambiguous meanings as a basis for judging between the disputed symbols fails. The whole "exception argument" has been articulated

or that in juridical proceedings a fair hearing of such complaints is denied" (Council of Europe, 1983: 24-25). This concept of "official tolerance" has been linked to the use of the disputed insignia in Croatia from the beginning of the 1990s until now. However, this analogy is mistaken since, unlike torture that was unconstitutional in Turkey, the salute For the Homeland Ready or other similar prima facie disputed insignia of hate have not been prohibited explicitly by the Croatian Constitution or by any legal act. Aside from various vague statements about general prohibition of intolerance, discrimination, and similar offences, the Croatian legal framework has never been explicit in banning particular symbolic expressions (unlike the Hungarian, for example), hence the "official tolerance" analogy is not applicable in that sense.

${ }^{47}$ In his dissenting opinion Željko Tanjić articulated this exception as a "minimal satisfaction" that legalizes "ZDS" (an abbreviation in Croatian for the salute Za dom spremni, or For the Homeland Ready); it is minimal since it "emphasizes the logic of double standards and of onefolded openings of the old wounds". Dissenting opinion on the Dialogue Document by Željko Tanjić, available at: https://vlada.gov.hr/UserDocsImages/Vijesti/2018/02\%20veljača/28\%20 veljače/Mišljenje\%20prof.\%20dr.\%20sc.\%20Željka\%20Tanjića.pdf. 
in a clumsy way. Instead of trying to prove that the de facto ambiguous symbolic expression should be viewed as unambiguous, the Council could accept the multiple meanings view and invoke the Fáber v. Hungary case-law since it, among all, deals with the controversial symbolic display as well as points toward the fact that the salute in the Croatian case was never officially banned. The judgment in its concluding statements highlighted the context when deciding about the legitimacy of displaying a multiple meanings symbolic expression, in this case the Hungarian Árpád flag. It says:

Assuming that the banner in question has multiple meanings - that is, it can be regarded both as a historical symbol and as a symbol reminiscent of the Arrow Cross regime - it is only by a careful examination of the context in which the offending expressions appear that one can draw a meaningful distinction between shocking and offensive expression which is protected by Article 10 and that which forfeits its right to tolerance in a democratic society... The Court stresses that ill feelings or even outrage, in the absence of intimidation, cannot represent a pressing social need for the purposes of Article $10 \S 2$, especially in view of the fact that the flag in question has never been outlawed. ${ }^{48}$

However, since the Council took a different argumentative route, in order to be consistent with its proposal and pursue the prima facie quality of the disputed salute as its key argument, the exception argument cannot be applied. As president Tuđman in the early 1990s as well as the Council in 2018 both concluded, the salute has been used in an illegitimate way during the Homeland War. Therefore, from the Council's argument that the salute has been used illegitimately and "contrary to the Constitution" it does not logically and legitimately follow that "an exception when it comes to the public use of the salute 'Za dom spremni (For the homeland ready)' might be taken into consideration" (ibid.: 27). The Council basically proposes a paradox: even though something was illegitimate from the very beginning, due to the passage of time and chaotic circumstances, it obtains legitimacy no matter how limited. ${ }^{49}$ If this is the Ustasha salute that has been used illegitimately by certain Croatian units during the Homeland War without any legal consequences, it follows that it should be banned as a prima facie symbol of hate according to the Document. In other words, if the prima facie stipulations regarding fascist symbols are taken seriously, than it would be contradictory to use these symbols even for commemorative purposes, just as it would be in the case of any other symbols from that group such as the Ustasha letter U, the German SS, or the Chetnik cockade.

${ }^{48}$ Fáber v. Hungary, ECtHR (2012), para. 54 and para. 56.

${ }^{49}$ It would be the same to claim that just because I decide to take someone's apartment, I would be legitimately using it after a while due to the passage of time and the fact that in these circumstances no one was able to throw me out of it. 
Still, there were at least a couple of possible arguments that the Council could deploy in this situation in order to resolve the problem of the controversial salute. First, it could be consistent with the prima facie stipulations in the way proposed by the Document. That would be possible if the Council challenged the narrative that legitimizes the use of controversial insignia based on the premise that many were fighting and dying under this symbol. The Council had to make a shift in its conclusions by arguing that the fact that some soldiers were killed "under this insignia" is of circumstantial, not predominantly of substantial quality. Namely, what really matters is that these volunteers were fighting for Croatia, and not what unit they served in, i.e. the military unit here is of secondary importance since it changes neither their role in the Homeland War nor the fact that they would likely be volunteers and Croatian soldiers if these insignia did not exist at all. Such argument would likely reduce confusions and inconsistencies and retain no exclusions in banning prima facie insignia of hate.

Second, it could defend freedom of speech. Since the Council invoked Article 10 of the European Convention that points toward the value of free speech and the dangers of curbing it, the Document failed to take this argument seriously, hence making no real efforts in defending free speech consistently. It is interesting that basically all dissenting opinions advocate refraining from further bans, especially Jakir who claims that every additional prohibition would likely be counterproductive:

... it is delusional to think that social conflicts, as part of every democratic society, could be minimized, or even eliminated through repressions and prohibitions, and also that additional prohibitions might only deepen the existing social divisions, and contribute to the new ones, as well as jeopardize the Constitutionally guaranteed freedom of expression and investigation. By fully accepting provisions of Article 39 of the Constitution which prescribes that any call or encouragement to war or the use of violence, national, racial or religious hatred or any form of intolerance, is prohibited and punishable, I cannot support a recommendation which can be interpreted as a commitment to the additional "explicit prohibition of public use of all prima facie disputed symbols"... I am convinced that it is easier for the democratic order to endure the negative consequences of displaying totalitarian symbols and those apologies for totalitarian regimes from some marginal groups and individuals, no matter how irrational, ethically repulsive, and harmful they are, then additional norms that might even be used for endangering freedom of speech and expression. ${ }^{50}$

50 Dissenting opinion on the Dialogue Document by Aleksandar Jakir, available at: https://vlada.gov.hr/UserDocsImages/Vijesti/2018/02\%20veljača/28\%20veljače/Mišljenje\%20prof.\%20 dr.\%20sc.\%20Aleksandar\%20Jakir.pdf. Ivan Savić follows a similar line of arguing in his dissenting opinion emphasizing that prohibitions are of little effect and they likely lead to counter effects. See: Dissenting opinion on the Dialogue Document by Ivan Savić, available at: 
Having in mind social divisions in Croatia, Jakir's approach advocates for the broadest possible free speech defense that is aligned with the constitutional framework, as well as for plural and multidimensional dealings with difficult memories, and promoting the dialogue and conciliatory behavior along with education, not penalization and prohibition in order to reduce social fragmentation and further politicization of trauma. Furthermore, due to the fact that "symbols - and their manipulation - themselves can constitute a form of resistance" (Miller-Idriss, 2017: 38-39), banning controversial symbolic expressions means curbing the space for free protest speech as well as for public defiance against the officially established political discourse.$^{51}$ If the use of disputed symbolic expressions does not entail any real and present danger, the free speech argument is opposed to the blanket prohibitions of that sort. Finally, focusing on education and not on prohibition is fundamental in facing the undemocratic regimes and their symbolic representations. Namely, while banning a symbol might be a symbolical defeat of the controversial symbolic expression, the idea and the narrative behind that symbol do not simply disappear; they survive in a different symbolic form. This is because symbolic functions can be attained through different symbolic forms - different emblems, markings, colors, practices, myths, etc. - that can change from time to time, depending on various (historical, cultural...) circumstances: "A change of a symbolic form does not automatically entail a change of symbolic function, because the same function can be achieved by new forms" (Cohen, 1976: 29). This is something the Document also failed to acknowledge.

\section{Epilogue: Silence after Silence, or a Policy of Organized Forgetting}

The French philosopher Maurice Merleau-Ponty once said: "my past has its space, its paths, its nameplaces, and its monuments" (Merleau-Ponty, 1964: 15). This past is alive and yields constitutive building blocks of our collective memories, symbols, and traumas. However, there is no one past to face - we have opposed versions of past events, opposed evaluations, hence opposed streams of memories in the present. Croatian society is riven to the point that we live parallel histories. We are split into two confronting streams of the past flowing next to each other, developing parallel, adamant, and selective one-dimensional narratives. Like in parallel universes,

https://vlada.gov.hr/UserDocsImages/Vijesti/2018/02\%20veljača/28\%20veljače/Dopunsko\%20 mišljenje\%20doc.\%20dr.\%20sc.\%20Vanja-Ivan\%20Savić.pdf. Željko Tanjić in his dissenting opinion is not clear since he suggests prohibition of communist symbols, but at the end advocates education instead of banning symbols. See: Dissenting opinion on the Dialogue Document by Željko Tanjić, available at: https://vlada.gov.hr/UserDocsImages/Vijesti/2018/02\%20 veljača/28\%20veljače/Mišljenje\%20prof.\%20dr.\%20sc.\%20Željka\%20Tanjića.pdf.

51 I am discussing this view more extensively in: Cvijanović, 2016. 
each stream has "its own past" (moments) both traumatic and glorious at the same time; its own monuments, songs, salutes, anniversaries and commemorations, even its own favorite colors; and each prefers to be silent about crimes of its own favorite heroes. In these parallel mnemonic universes there is a competition among the two streams of the past in proving which one was more horrible, more exculpable, who committed more crimes, whose crimes are the gravest, whose trauma is the greatest. Croatian memory wars results from a divided society that has been struggling with its difficult past since WWII, a society in which WWII is not over yet, so each side still counts the bones of the dead.

After decades of silencing memories of the defeated and the crimes committed by "the hand of justice, the hand of retribution", ${ }^{52}$ another veil of deafening silence regarding the scale of the "fascist crime" is rising. This silence is noticeable in various revisionist takes on the NDH history (including those about detainees having a great time there) whose purpose is to shift focus on the communist terror. However, this silence after silence is nothing else but a policy of organized forgetting. ${ }^{53}$ When the Dialogue Document is silent about the "fascist crime" in interpreting and evaluating the past, but resolute about the communist crimes at the same time, this contributes to such policies of organized forgetting, hence discrediting its mission to confront equally the consequences of both undemocratic regimes. In that sense, the Document fails in its conciliatory attempts and allows to be seen as just another

52 This oxymoron that merged justice and retribution is an excerpt from Josip Broz Tito's speech held in Ljubljana, Slovenia, on 27 May 1945 and it is related to the mass executions of the defeated NDH captives: "As for these traitors found within our country, in every nation especially - it's a thing of the past. The hand of justice, the hand of retribution of our people, has reached the vast majority of them." See: http://www.novosti.rs/dodatni_sadrzaj/clanci.119.html:539789Ruka-osvetnica-na-delu.

53 Page uses this expression as well the term "deafening silence" as an inadequate "typical response to the fascist past" pointing at the presence of Mussolini's heritage in Italy, both in terms of architecture as well as political life (Page, 2014; 2016: 134-140). A policy of organized forgetting as a sort of revisionist narrative has been present in Croatia from the late 1980s on, especially when discussing the concentration camp Jasenovac. Tuđman's estimations reduced the number of victims to $30000-40000$ as well as suggested that Jews were responsible for the administration and even for some killings (Tuđman, 1989: 316-320, in: Radonić, 2012). Also, in her analysis of the parliament speeches from 1999 related to the crimes from the past, Radonić shows that speeches were focused on Serbian crimes without mentioning Jasenovac at all (Radonić, 2012: 169). This pattern reappears in the media through the narratives of Croatian victimhood on the one hand, as well as in a form of relativization of the fascists' crimes via various book presentations or revisionist documentaries such as Jakov Sedlar's JasenovacThe Truth (2016), on the other hand. Finally, there are permanent political tensions regarding the weight that has to be given either to the Bleiburg commemoration or the one in Jasenovac (for more on these tensions, especially concerning Bleiburg and other sites of communist Partisans' atrocities, see: Pavlaković et al., 2018). 
ideological perspective. On top of that, the Document is, as I have shown earlier, confusing, inconsistent and self-defeating in its recommendations regarding disputed insignia of hate, more particularly in its evaluations of the five-pointed red star controversy and the salute For the Homeland Ready. All its recommendations cannot be applied coherently since the Document does not take its own principles seriously when discussing these controversial symbolic expressions, but is rather shopping around from the cases, examples, and exceptions arbitrarily.

In order for the Document to be consistent with its logic of arguing, it should either be vehement in penalizing all symbolic expressions that provoke "uneasiness" or can be in any way linked to traumas of the past regimes, totalitarian terrors, and other shameful things that tainted particular symbolic expressions, or it should adopt a view on freedom of speech as it is outlined in Article 10 of the Convention, if not even allow for all symbols to be displayed equally no matter whose feelings might be disturbed. My own view is that removing/banning symbolic expressions falls short in cooling down Croatian memory wars and healing social divisions, as well as in reducing extremism and intolerance. Any banned symbol or symbolic expression does not yield real possibility of removing the frameworks of ideas behind them. We can legally remove all symbols of hate, but they still might be residing in our minds. Furthermore, imposing legal frameworks on possible interpretations of various symbolic expressions, or over conflicting memories (as it was the case with the Parliament's Declaration on the Homeland War) euthanizes and depoliticizes the public sphere, and as such restricts individual freedom of expression beyond the state-sanctioned boundaries. Confronting is not silencing, nor forgetting, but discrediting and educating about socially dividing narratives and symbolic expressions that keep us locked in the past.

\section{REFERENCES}

Alejandro, Roberto. 2011. Nietzsche and the Drama of Historiobiography. University of Notre Dame Press. Notre Dame.

Belavusau, Uladzislau. 2013. Freedom of Speech: Importing European and US Constitutional Models in Transitional Democracies. Routledge. London/New York.

Belavusau, Uladzislau \& Gliszczyńska-Grabias, Aleksandra (eds.). 2017. Law and Memory: Towards Legal Governance of History. Cambridge University Press. Cambridge, UK.

Berger, Arthur Asa. 2006. 50 Ways to Understand Communication. Rowman \& Littlefield Publishers, Inc. Lanham/Boulder/New York/Toronto/Oxford. 
Berger, Arthur Asa. 2010. The Objects of Affection: Semiotics and Consumer Culture. Palgrave Macmillan. New York.

Bernal, Angelica M. 2017. Beyond Origins: Rethinking Founding in a Time of Constitutional Democracy. Oxford University Press. New York.

Bernhard, Michael \& Kubik, Jan (eds.). 2014. Twenty Years After Communism: The Politics of Memory and Commemoration. Oxford University Press. Oxford.

Cipek, Tihomir. 2017. The Spectre of Communism is Haunting Croatia. The Croatian Right's Image of the Enemy, Croatian Political Science Review, (54) 1-2: 150-169.

Cohen, Abner. 1976. Two-Dimensional Man: An essay on the anthropology of power and symbolism in complex society. University of California Press. Berkeley and Los Angeles.

Council of Europe, 1983. Yearbook of the European Convention on Human Rights. Kluwer Academic Publishers. Dodrecht/Boston/Lancaster.

Cvijanović, Hrvoje. 2016. Govor kao verbalni i simbolički prostor slobode i političkog: američki poučak i govor mržnje u EU i Hrvatskoj, in: Kulenović, E. (ed.): Govor mržnje u Hrvatskoj. Fakultet političkih znanosti Sveučilišta u Zagrebu. Zagreb: 61119.

Đurašković, Stevo. 2016a. The Politics of History in Croatia and Slovakia in the 1990s. Srednja Europa. Zagreb.

Đurašković, Stevo. 2016b. National identity-building and the "Ustaša-nostalgia", Croatia: the past that will not pass, Nationalities Papers, 44: 1-16.

Gigliotti, Simone (ed.). 2017. The Memorialization of Genocide. Routledge. London.

Heinze, Eric. 2017. Epilogue: Beyond 'Memory Laws': Towards a General Theory of Law and Historical Discourse, in: Belavusau, Uladzislau \& Gliszczyńska-Grabias, Aleksandra (eds.): Law and Memory: Towards Legal Governance of History. Cambridge University Press. Cambridge, UK: 413-433.

Kasapović, Mirjana. 2018. Genocid u NDH: Umanjivanje, banaliziranje i poricanje zločina, Croatian Political Science Review, (55) 1: 7-33.

Koskenniemi, Martti. 2011. Law, Teleology and International Relations: An Essay in Counterdisciplinarity, International Relations, (26) 1: 3-34.

Malcolm, Noel (ed.). 1994. The Clarendon Edition of the Works of Thomas Hobbes, Vol. 6: The Correspondence, Vol. 1: 1622-1659. The Clarendon Press. Oxford, UK.

Margalit, Avishai. 2002. The Ethics of Memory. Harvard University Press. Cambridge, MA.

Marx, Karl \& Engels, Friedrich. 1978. Manifesto of the Communist Party, in: Tucker, Robert (ed.): The Marx-Engels Reader. W.W. Norton \& Company. New York \& London: 469-500.

Merleau-Ponty, Maurice. 1964. Signs. Northwestern University Press. Evanston, IL. 
Milekic, Sven. 2017. Why Croatia's President Tudjman Imitated General Franco. Balkan Transitional Justice, http://www.balkaninsight.com/en/article/why-croatia-s-president-tudjman-imitated-general-franco-10-12-2017 (retrieved 13 May 2018).

Miller-Idriss, Cynthia. 2017. The Extreme Gone Mainstream: Commercialization and Far Right Youth Culture in Germany. Princeton University Press. Princeton \& Oxford.

Nietzsche, Friedrich. 1994. On the Genealogy of Morality. Cambridge University Press. Cambridge, UK.

Olick, Jeffrey. 1999. Collective Memory: The Two Cultures, Sociological Theory, (17) 3: 333-348.

Page, Max. 2014. The Roman architecture of Mussolini, still standing. Boston Globe, https://www.bostonglobe.com/ideas/2014/07/12/the-roman-architecture-mussolini-still-standing/csZ70EN2fTnUUNqX0kRM9K/story.html (retrieved 8 August 2018).

Page, Max. 2016. Why Preservation Matters. Yale University Press. New Haven.

Pauković, Davor. 2012. The Role of History in Legitimizing Politics in Transition in Croatia, in: Pauković, Davor et al. (eds.): Confronting the Past: European Experiences. Political Science Research Centre. Zagreb: 183-219.

Pavlaković, Vjeran et al. 2018. The Controversial Commemoration: Transnational Approaches to Remembering Bleiburg, Croatian Political Science Review, (55) 2: 7-32.

Preston, Paul. 1995. The Politics of Revenge: Fascism and the Military in $20^{\text {th }}$-century Spain. Routledge. London and New York.

Radonić, Ljiljana. 2012. Croatia's Transformation Process from Historical Revisionism to European Standards, in: Pauković, Davor et al. (eds.): Confronting the Past: European Experiences. Political Science Research Centre. Zagreb.

Stockey, Gareth. 2013. Valley of the Fallen: the (n)ever changing face of General Franco's monument. Critical, Cultural and Communications Press. Nottingham.

Tokić, Mate Nikola. 2018. Avengers of Bleiburg: Émigré Politics, Discourses of Victimhood and Radical Separatism during the Cold War, Croatian Political Science Review, (55) 2: 71-88.

Veselinović, Velimir. 2016. Franjo Tuđman i pravaši, Croatian Political Science Review, (53) 1:71-102.

\section{Documents}

Dialogue Document: Postulates and Recommendations on Specific Normative Regulation of Symbols, Emblems and other Insignia of Totalitarian Regimes and Movements, the Council for Dealing with the Consequences of Undemocratic Regimes, February $28^{\text {th }} 2018$ (Zagreb), available at: https:/vlada.gov.hr/UserDocsImages// 
Vijesti/2018/05\%20svibanj/5\%20svibnja//DOKUMENT\%20DIJALOGA\%20 ENG.pdf (retrieved 4 May 2018).

Dissenting opinion on the Dialogue Document by Željko Tanjić, available at: https:/vlada.gov.hr/UserDocsImages/Vijesti/2018/02\%20veljača/28\%20veljače/ Mišljenje\%20prof.\%20dr.\%20sc.\%20Željka\%20Tanjića.pdf (retrieved 9 October 2018).

Dissenting opinion on the Dialogue Document by Mladen Ančić, Nataša Jovičić, Ivo Lučin, Ante Nazor, and Nevio Šetić, available at: https://vlada.gov.hr/UserDocsImages/Vijesti/2018/02\%20veljača/28\%20veljače/Mišljenja\%20prof.\%20dr.\%20 sc. $\% 20$ Mladena $\% 20$ Ančića $\% 2$ c \%20Nataše\%20Jovičić\%2c\%20dr.\%20sc. $\% 20$ Ive\%20Lučića\%2c\%20doc.\%20dr.\%20sc.\%20Ante\%20Nazora\%20i\%20prof.\%20 dr.\%20sc.\%20Nevija\%20Šetića.pdf (retrieved 9 October 2018).

Dissenting opinion on the Dialogue Document by Ivan Savić, available at: https:/vlada. gov.hr/UserDocsImages/Vijesti/2018/02\%20veljača/28\%20veljače/Dopunsko\%20 mišljenje\%20doc.\%20dr.\%20sc.\%20Vanja-Ivan\%20Savić.pdf (retrieved 9 October 2018).

Dissenting opinion on the Dialogue Document by Aleksandar Jakir, available at: https:// vlada.gov.hr/UserDocsImages/Vijesti/2018/02\%20veljača/28\%20veljače/ Mišljenje\%20prof.\%20dr.\%20sc.\%20Aleksandar\%20Jakir.pdf (retrieved 9 October 2018).

Hasanbegović predsjednici: Ne, "za dom spremni” nije stari hrvatski, nego ustaški pozdrav, in: Novi list, available at: http://www.novilist.hr/Vijesti/Hrvatska/ HASANBEGOVIC-PREDSJEDNICI-Ne-za-dom-spremni-nije-stari-hrvatski-nego-ustaski-pozdrav (retrieved 18 October 2018).

\section{Case-law}

Vajnai v. Hungary, the European Court of Human Rights (2008).

Fáber v. Hungary, the European Court of Human Rights (2012).

Slovenian Constitutional Court case-law on The Ordinance on Determining and Changing the Names and Course of the Roads and Streets in the Territory of Ljubljana Municipality (Official Gazette RS, No. 44/09), Article 2, see: http://odlocitve.us-rs. si/en/odlocitev/AN03530?q=u-i-109\%2F10

Mailing Address: Hrvoje Cvijanović, Faculty of Political Sciences, University of Zagreb, Lepušićeva 6, 10000 Zagreb.E-mail: hrvoje.cvijanovic@fpzg.hr 